\title{
Introdução a uma leitura de Espinosa ${ }^{1}$
}

Introduction to a Reading of Spinoza

\section{Homero Santiago}

Universidade de São Paulo (USP)

\section{RESUMO}

Ao longo de décadas, a filósofa brasileira Marilena Chaui produziu uma das mais vigorosas e importantes interpretaçóes da filosofia espinosana. Nossa intenção é propor uma introdução a essa leitura. Queremos mostrar como, ao mesmo tempo em que seus passos iniciais vinham na esteira da redescoberta francesa de Espinosa nos anos 6o, essa interpretação, segundo relato da própria autora, foi elaborada nos anos 70 "sob o signo da crítica da ditadura”, de tal forma que, ali, a história da filosofia fosse praticada como "crítica do instituído", ou ainda mais precisamente, como esforço compreensivo e crítico do autoritarismo brasileiro. Quais as circunstâncias dessa operação? É o que pretendemos investigar.

\section{PALAVRAS-CHAVE}

Marilena Chaui; Espinosa; Brasil; Autoritarismo.

\begin{abstract}
Over five decades, the Brazilian philosopher Marilena Chaui produced one of the most vigorous and important interpretations of Spinoza's philosophy. In this paper we intend to propose an introduction to this reading. We would like to show how, at the same time, this interpretation I) has its initial steps in the wake of Spinoza's French rediscovery in the 1960s; 2) according to the author's own report, it was elaborated mainly in the 70's "under the sign of the criticism of the dictatorship", and in this reading the history of philosophy was practiced as "critique of that which has been instituted", or even more precisely, as a comprehensive and critical analysis of Brazilian authoritarianism. Which are the circumstances of this operation? It is what we intend to investigate.
\end{abstract}

\section{KEY WORDS}

Marilena Chaui; Spinoza; Brazil; Authoritarianism.

\footnotetext{
1 O texto é uma versáo levemente adaptada do primeiro capítulo de um volume sobre a leitura de Espinosa por Marilena Chaui nos anos 70 e 80, trabalho realizado no âmbito do projeto temático "Poder, conflito e liberdade: Espinosa e os percursos da filosofia política moderna e contemporânea acerca da democracia", financiado pela Fapesp (2018/19880-4)
} 
O que é ler Espinosa?

Chaui, I971a, p. 107

Por que ainda hoje alguém lê Espinosa? Epor que, além de herdar silenciosamente seu discurso, deseja escrever também.

Id., I977, I, p. 2

Com a publicação do segundo volume de $A$ nervura do real (Chaui, 2016), Marilena Chaui deu acabamento a uma das mais ricas e sólidas leituras da obra de Espinosa já produzidas pela fortuna crítica do filósofo. O termo "leitura", no caso, precisa entender-se em seu sentido mais forte: o resultado tangível de uma meditação, ou antes, uma "conversa" (como prefere a própria leitora ${ }^{2}$ ) que se estende por mais de cinco décadas no esforço de considerar de maneira aprofundada a completude do espinosismo; um trabalho que, além de estabelecer perspectivas originais e renovar em inúmeros pontos a literatura especializada, exibe um caráter muito pessoal e ultrapassa a fronteira da mera disputa tética, assentando-se em algumas especificidades marcantes como, por exemplo, do lado do objeto, a reiterada defesa da primazia política do pensamento espinosano e de sua singularidade no interior da história do pensamento, ou, do lado da estudiosa, a meticulosa análise do processo de construção da imagem do espinosismo bem como a preocupação em tornar essa interpretação acessível a um público amplo, devendo aliás Marilena ser reconhecida como um dos pilares do amplo interesse que tal filosofia desperta hoje no Brasil (cf. Oliva, 2020). Tendo em conta todas essas particularidades, e sem querer diminuir nenhuma delas, já que efetivamente implicam cada uma à sua maneira reais inovaçóes interpretativas no âmbito dos estudos espinosanos, gostaríamos de identificar e salientar uma que, em nosso entender, está na base de todas as outras, assim como as fundaçôes estão para os edifícios, justificando dessa maneira atribuir à miríade de textos que se desdobram por cinquenta anos o rigoroso estatuto de uma leitura: certa concepção do que seja ler, e particularmente o que seja ler um texto filosófico. Ainda que pareça meio truísta, no fundo não é, pois a originalidade maior dessa leitura reside muito precisamente na maneira como Marilena concebe o ato mesmo de ler. É que a questão, muito longe de se resumir a uma trivial tomada de posição entre metodologias concorrentes (praxe tanto mais banal quanto mais se busca justificá-

2 O termo foi utilizado por Marilena quando do lançamento do Nervura do real II no Departamento de Direito da PUC-Rio em 22 de novembro de 2016. 
la!), traz enormes implicaçôes e abrange não apenas a leitura propriamente dita como também as suas condiçóes (a produção da obra e as relaçóes entre o pensador e o seu tempo) e potencialidades (as relaçóes entre aquele pensamento que se fez obra e o tempo em que esta é lida). Para falar sumariamente, trata-se de uma questão que gira em torno da essência mesma do que a leitora Marilena costuma denominar a obra de pensamento.

A problemática e as interrogaçóes concernentes a esse conceito provavelmente começaram a delinear-se muito cedo a Marilena, já ao tempo de sua lida com a filosofia de Merleau-Ponty para a elaboração da dissertação de mestrado defendida em 1967, e persistiram sem cessar ao longo de décadas de trabalho filosófico e docente. Este autor pôde testemunhar a admirável envergadura temporal dessa meditação em 7 de agosto de 20I9, quando a professora Marilena Chaui, nos minutos iniciais de sua aula aos primeiranistas de Filosofia da Universidade de São Paulo, numa sala em que as dezenas de estudantes e ouvintes precisavam ser contadas com o auxílio dos dedos das mãos e dos pés, explicar com paciência a diferença entre "contexto" (a história exterior ao texto) e "circunstância" (a "experiência" do autor), e como a distinção é crucial para a boa formulação do que seja uma obra de pensamento. A professora e escritora náo perde oportunidade de avançar esclarecimentos desse tipo, como a permitir aflorar livremente o que pode até passar por inveterada obsessão historiográfica de mais de cinco décadas. Talvez o seja, contanto entendamos isso adequadamente, ou seja, no sentido em que a própria Chaui (1971a, p. 27; I97Ib, p. 7I) fala da "obsessáo" espinosana pelo exemplo da quarta proporcional, apresentado no Breve tratado, no Tratado da emenda do intelecto e na Ética, ou ainda a "obsessão" do filósofo em interrogar as prime significationes das palavras. Nesse sentido preciso e imune ao ranço psicologizante, as obsessivas consideraçóes historiográficas de Marilena constituem o testemunho da intermitente reposição do problema da leitura e da escrita em filosofia; noutros termos (e para de uma vez por todas afastar a ideia de que falamos de corriqueira escolha no mercado das opçóes metodológicas), uma robusta reflexão filosófica sobre os atos de ler e de escrever que se dirige àquela regiáo em que, sem o esfumaçamento dos limites entre a obra lida e a obra produzida a partir dela, torne-se possível uma comunicação, uma "conversa" entre elas, engajando quem escreveu e quem lê, graças ao trabalho do pensamento veiculado pela obra de pensamento em sua relação inextricável com a linguagem, uma vez que só "existe obra quando a escrita tem o poder de suscitar não apenas leituras, mas outras escritas, que devem à primeira o que esta lhes deu a pensar e a dizer" (Id., 20I8c, p. 33). Em sendo assim, é natural que a questão da leitura desemboque numa particular concepção do que seja a história da filosofia como disciplina e de sua relação com o filosofar cujo centro nervoso é a noção de trabalho da obra, 
a qual nos insere no universo específico (uma consistência e uma temporalidade particulares) dos objetos culturais e não por acaso, aos olhos da professora Marilena, é a via privilegiada para a formação em filosofia e a constituição da possibilidade de interrogar o próprio presente. ${ }^{3}$

É impossível exagerar a centralidade dessa reflexão para a leitura de Espinosa produzida por Marilena; ela responde, insistamos no juízo, por sua originalidade maior. Algo tanto mais notável quanto mais nos damos conta do imbricamento das duas coisas, ou seja, conforme melhor se perceber que foi no bojo do trabalho sobre as obras espinosanas que aquela reflexão pôde florescer plenamente. Por isso, vistas as coisas por esse ângulo, pensamos ser cabível identificar o momento inaugural dessa elaboração na tese de doutorado intitulada Introdução à leitura de Espinosa que Marilena finalizou em 1970 e defendeu no ano seguinte na Faculdade de Filosofia, Letras e Ciências Humanas da Universidade de São Paulo.

A autora costuma não ser especialmente generosa com esse trabalho, que ela já classificou de "ingênuo" e, pior, "fracassado"; ${ }^{4}$ em suas palavras, longe de constituir um momento determinante de seu percurso por Espinosa, a tese náo passaria do arranjo apressado de "um conjunto de notas sobre o Tratado teológico-político", que por isso mesmo ganhou o nome de Introduçâo à leitura de Espinosa (Id., 2007, p. 57). Ora, ainda que a modéstia do título, por um lado, faça as vezes de alerta sobre a incipiência do resultado de um itinerário de estudos precocemente interrompido por razóes de que logo falaremos, ele é por demais sugestivo para que, por outro lado, tomando-o literalmente e nos permitindo discordar da própria autora, não o compreendamos como a pedra fundamental do edifício interpretativo a ser erguido nas décadas seguintes. ${ }^{5}$ Com efeito, é difícil desconsiderar que uma de suas operaçôes centrais, aquela que prepara o sentido mais profundo do texto, é precisamente a extensa problematização do ato de ler um filósofo. Trata-se ali menos de introduzir

3 Cf. Chaui, 2018d, p. 540: "Considero a história da filosofia o esteio teórico da formaçâo filosófica e condiçấo para a interrogação de nosso presente. Isso evidentemente pressupóe uma certa concepçáo da história da filosofia, qual seja: cada filósofo, em seu presente e nas suas circunstâncias, interroga a experiência, os dados e os acontecimentos que lhe são contemporâneos; é por sua imersão na particularidade de seu tempo que ele alcança o universal; suas respostas não são nem podem ser as nossas, mas com ele aprendemos a interrogar nosso próprio presente.” A mais aprofundada formulaçáo dessa concepçáo de história da filosofia encontrase em id., 2018b.

4 Cf. Chaui, 200I, p. I406; o adjetivo "fracassado" foi usado pela autora no lançamento do Nervura do real II no Departamento de Filosofia-USP, em 27 de setembro de 2016.

5 A discordância, para falar a verdade, nem carece de ser muito grande, pois a própria recém-doutora, respondendo por escrito à arguiçáo do prof. Arnold von Bugenhagen, alertava para a peculiaridade assumida pelo termo "introduçáo" no título da tese. Em vez de introduçáo estabanada que já lançasse o leitor no meio de uma série de complexos problemas da interpretação espinosana, o aspecto introdutório é a ser entendido assim: "proponho um começo e faço uma tentativa para ler Espinosa com novos parâmetros, estabelecendo a inadequação daqueles que sempre foram propostos para isto. Trata-se de uma introdução à leitura de Espinosa, donde o caráter exegético de todo o início de minha tese." (Chaui, I97Ic, p. I) 
ao espinosismo (coisa que a autora virá a fazer com mestria noutros momentos) do que a uma maneira determinada de ler de Espinosa; propósito que imediatamente póe o problema da leitura e a leitura como problema, ultrapassando em muito os limites de um protocolar status quaestionis e nos permitindo reconhecer, em estado nascente mas já assumindo formas definidas entre tateios e experimentaçôes, a peculiar concepção de leitura que afirmamos correr subjacente a toda a leitura de Espinosa por Marilena.

Seremos acusados de deslavado anacronismo? Não é para tanto. Uma ou outra pitada, sem dúvida, mas naquela medida que ajuda a bem temperar a interpretação sem desandá-la. Estamos disso convencidos porque tais questóes, por volta do momento de elaboração da tese, nem era inéditas nem estavam longe de alcançar a consciência. Retornemos a meados da década de 1960, quando a mestranda está debruçada sobre os textos de Merleau-Ponty. Como sabe todo aquele que algum dia leu umas páginas desse filósofo, é muito difícil, se não impossível, estudá-lo sem deixar-se sensibilizar pela problemática das relaçôes entre a leitura e a interpretação das obras de pensamento. Marilena não é exceção. Pelo contrário, até ousará um passo além: não apenas saudar e tematizar os leitmotiven do filósofo francês relativos ao assunto, restringindo-se à praxe, como se servir desse arsenal para interpretar a própria filosofia de que decorrem - e começando assim a trilhar o caminho que a levará a produzir o que numa expressiva imagem designou-se "um uróboro filosófico", quer dizer, ela lê Merleau-Ponty da maneira como este lê os filósofos (Siviero, 20I7, p. 265). É o que encontramos em estado nascente quando Chaui (1967, p. 29I) reconhece no problema da formação das idealidades a partir da rejeição da separação entre o visível e o invisível o "impensado" do filósofo; ou, após determinar a "intuição original" da filosofia merleau-pontyana "na afirmação de que a vida representativa da consciência não é nem a primeira, nem a única” (Ibid., p. 240), alinha-se à crítica à noção bergsoniana de "obra filosófica como explicitação impossível da intuição do filósofo", com palavras incisivas que deverão nos inspirar adiante:

Náo que Merleau-Ponty negue uma intuição original. O que ele nega é a existência de uma coincidência tal do pensamento consigo mesmo, anterior a toda palavra, e que linguagem alguma seria capaz de apreender. Nega-se a aceitar que 'a linguagem seja uma potência de erro', que cortaria nossos laços com as coisas e com o passado. (Ibid., p. 282-283)

${ }^{6}$ A passagem de Le visible et l'invisible que se tem em mira provém de Merleau-Ponty, 2006, p. 166. 
Não por acaso, permitindo-nos saltar alguns anos, essa denúncia d'O visivel e 0 invisivel contra uma má concepção da linguagem que anima o comentário de Marilena entronca perfeitamente com as primeiras linhas de um artigo de 1971 publicado na esteira do doutorado e que criticam com aspereza Martial Gueroult, cuja concepção de linguagem, por trilhas bem diferentes das de Bergson, igualmente culmina na interdição de nossas relaçôes "com as coisas e com o passado".

Gueroult lastima não ter Espinosa se dedicado ao problema da expressão linguística das ideias, justo esse filósofo que "concebe entre a palavra e a ideia o abismo que separa a imaginação do intelecto, o falso do verdadeiro" (Gueroult, 1968, p. I60, apud Chaui, I97ıb, p. 69). Nem por isso, adverte, essa "impropriedade inexpiável da linguagem" franqueará ao leitor o direito de substituir as palavras do próprio autor e atribuir-lhe outros sentidos, dando vazão ao exercício de uma imaginaçáo mais ou menos metódica, isto é, interpretando. "Científica", "objetiva”, para Gueroult "a palavra de ordem da história da filosofia é um categórico: Non interpretandum." (Chaui, I97Ib, p. 69) Contra a dubiedade da linguagem, posta-se a certeza de que ela pode exprimir tudo o que tem a dizer; contra a guerra dos dogmas, a profilática renúncia à verdade material deles, já que no fundo todo filósofo pretende a universalidade; e por aí vai a cartilha que, seguida à risca pelo leitor, terminará por lhe conferir o curioso privilégio de habilitar-se à produção final de uma "cópia-conforme da doutrina" que talvez escapasse até ao próprio filósofo. A dura crítica de Marilena a esse ideal de plena coincidência entre escritor e leitor graças a uma linguagem capaz de exprimir tudo o que se deseja exprimir pela escrita e fazer apreender tudo que se quer apreender pela leitura evidencia que uma outra concepçáo de história da filosofia está já em açáo; e sequer é necessária muita interpretação para que o percebamos.

O historiador interpreta porque acredita na vacilação das palavras. Não procura outra filosofia no filósofo, mas quer filosofar com ele. Desconfia da objetividade e busca o impensado; náo aquilo que o filósofo náo pensou e que o intérprete pensaria em seu lugar, mas aquilo que deixou para se pensasse com ele e a partir dele. É esta sua herança. O historiador não recusa o papel de funcionário, mas não quer assumir o de mero escriturário. (Ibid., p. 69-70)

É exatamente entre esses dois momentos correlacionados por argumentos semelhantes e pela comum exigência de filosofar com o filósofo lido que se situa a tese de doutorado e sua prolongada meditação sobre o problema da leitura. Convém náo negligenciar esse pormenor. É ali que Marilena começa a esboçar e exercitar certa maneira de ler Espinosa que doravante se apresentará em todos os seus textos dedicados ao filósofo, e a operaçáo historiográfica justifica-se precisamente na medida em que prepara o sentido maior do trabalho. Se obra de pensamento é aquela que, 
uma vez lida, faz-se capaz de pôr em movimento o pensamento do leitor e suscitarlhe a escrita, mais que isso é também a obra que não se deixa nunca agarrar por completa. Ela é um "fazer-se discurso" na medida em que "institui uma posteridade de interpretaçóes", e aquilo que nela existe, "uma vez posto pelo discurso do escritor, não pode mais deixar de ser retomado pelos discursos dos leitores" (Id., 20I8b, p. 555). Mas uma retomada que não se orienta, senão traindo a essência mesma da obra de pensamento, pela repetição. O discurso lido é "capaz de suscitar de maneira nova questôes que são nossas" (Id., I977, I, p. 3). A reflexão em outrem não é nem apropriação nem coincidência; filosofar com o filósofo é interrogar sua obra com vistas a aprender a interrogar o próprio tempo. Por isso não deve surpreender que diferentes formas de leitura culminem em diferentes discursos, ou entáo, reciprocamente, que diferentes discursos pretendidos exijam, para sua produção, diferentes tipos de leitura. Assim, por exemplo, Gueroult lê como kosmotheoros porque seu escopo é a produção de um discurso científico sobre os monumentos do passado; ${ }^{7}$ já "Merleau-Ponty", explicará Marilena alhures, "lê para escrever como filósofo" e por isso sua obra localiza-se "na esteira de outras que lhe deram a pensar" (Id., I98I, p. 2II-2I2); e o próprio Espinosa, como esquecê-lo?, um leitor de mão cheia que se debruça sobre os textos cartesianos e os do Antigo Testamento sempre amparado por uma aguda reflexão acerca dos limites e potencialidades da interpretação.

Esse nexo que se estende entre o ato de ler e o resultado discursivo da leitura nos convence que a singela questão “o que é ler Espinosa?" envolve uma série de consequências nem um pouco simples; pelo contrário, é inseparável daquela outra que Marilena se fará poucos anos depois mas que temos o direito de lançar ao texto de I970: “por que ainda hoje alguém lê Espinosa?". A bem dizer, razóes não faltavam, pois então se assistia à intensa retomada do interesse pelo filósofo. Em 1968 aparecem na França os trabalhos de Martial Gueroult (Spinoza. Dieu) e de Gilles Deleuze (Spinoza et le problème de l'expression); no ano seguinte, vem o inaugural trabalho sobre a política espinosana de Alexandre Matheron (Individu et communauté chez Spinoza); ao lado disso tudo, estava Louis Althusser e seu grupo relendo Marx a partir de um inusitado "desvio" por Espinosa - em suma, o espinosismo estava mais ou menos na ordem do dia. Todavia, aprofundando o liame há pouco estabelecido, temos de perguntar, não só por que ler Espinosa e escrever sobre Espinosa, como também e sobretudo por que lê-lo do jeito como ali Marilena o lê e escrever o que sobre ele escreve. É esse complexo de questôes que nos conduz finalmente ao

\footnotetext{
Para a qualificação de Gueroult como kosmotheoros, cf. Chaui, I97ıa, p. I07, I09; I97Ib, p. 70. Em id., 2002, p. 2IO, explica-se assim a "posição do kosmotheoros": "espectador absoluto, geometral de todos os pontos de vista, situado fora do espaço e do tempo, livre da localidade e da temporalidade que 'contaminam' a autonomia indispensável para a posição do universal e do verdadeiro."
} 
ponto. A detida discussão de alguns marcos da interpretação espinosana e problemas relacionados à própria concepção de história da filosofia no doutorado de 1970 tem o objetivo de, vencendo o abismo entre as épocas, articular uma aliança entre "investigação" e "aquisição" que sirva de franquia, no plano historiográfico tanto quanto no filosófico, a um uso do espinosismo como instrumento de resistência ao presente ditatorial sob que o trabalho é elaborado e a uma indagação acerca das possibilidades de transformação daquela situação tenebrosa. A reboque da voga espinosana, ela efetivamente nos apresenta um Espinosa "meia-oito", só que um filósofo lido pelo prisma do 68 brasileiro e suas decorrências. Um Espinosa que evoca menos os paralelepípedos e bordóes libertários do maio parisiense que a decretação do AI-5 e o embrutecimento da ditadura instalada no Brasil em 1964, as dolorosas tribulaçóes dos torturados, a tragédia da luta armada, a dor dos exilados, a necessidade de resistir.

É a própria quem, num depoimento, reconhece e justifica esse expediente que da historiografia salta à militância filosófica de profunda motivação política e enfeixa todos os seus textos sobre Espinosa ao longo da década de 70, incluindo portanto não somente o doutorado como também a tese de livre-docência, terminada em I976, e todo um conjunto de ensaios produzidos naqueles anos:

Sob o AI-5, as lutas revolucionárias estavam vencidas e a ditadura e o terror de Estado passavam à sua fase mais aguda e sombria. [...] Vivíamos no medo permanente, nunca sabendo se estaríamos vivos no dia seguinte, se nossos amigos e estudantes teriam desaparecido, sido presos, torturados, mortos ou exilados. Nossos professores haviam sido cassados e éramos vigiados e censurados dentro e fora da universidade. Precisávamos praticar a filosofia como crítica do instituído, mas fazê-lo tomando como símbolo a divisa de Espinosa "Cautela!". Foi sob o signo da crítica da ditadura, do autoritarismo e da ideologia da segurança nacional que, durante os anos de 1970, escrevi meu doutorado e minha livre-docência sobre Espinosa, encontrando em sua obra um pensamento que interroga seu contrário, que vai até o fundo mais profundo da origem do medo e de seus efeitos: a superstiçáo, a tirania e a servidão, cujas contradiçôes exigem o trabalho da interrogaçáo que se abre para a verdade e para a liberdade porque nasce do desejo de verdade e de liberdade. (Id., 20I8a, p. 27)

Marilena lê e escreve porque se sente visada pelo espinosismo; de alguma maneira, faz passado e presente se comunicarem. ${ }^{8} \mathrm{O}$ caráter eminentemente político da obra espinosana, sobretudo a "coragem de Espinosa" inspira, faz pensar e suscita o desejo de escrever (Id., I977, I, p. 4). No intuito de compreender o alcance e o

\footnotetext{
8 "O desejo de escrever nasce, acredito, quando no presente nos sentimos visados pelo passado" (Chaui, I977, I, p. 3)
} 
significado desse empreendimento e assim fazer jus ao juízo da filósofa de que "é preciso interrogar a própria emergência da leitura e de um novo discurso nascido do ato de ler" (Id., 20I8b), tratemos de brevemente repassar algumas das circunstâncias, ou antes o "fluxo e refluxo da história pessoal e social", em cujo interior deu-se essa experiência de pensamento, que recuperando o passado e interrogando o presente, mobiliza Espinosa contra a ditadura militar brasileira.'

Em 1967, Marilena Chaui defende sua dissertação de mestrado sobre Merleau-Ponty e a crítica do humanismo e abandona as aulas de filosofia no Colégio Alberto Levy, onde ensinava desde 1965, para tornar-se professora do Departamento de Filosofia da USP. Ao ingressar no doutorado, ela, que de início pretendia persistir na mesma senda investigando a relação entre fenomenologia e existencialismo, é incentivada ao estudo de um "clássico"; volta-se então a Espinosa, que, segundo confessa, havia tempos que "secretamente desejava estudar", deixando de fazê-lo no mestrado por considerá-lo um "filósofo muito acima de [suas] forças" (Id., 2000, p. 304).

Donde esse anelo furtivamente cultivado em meio aos interesses fenomenológicos? Espinosa fora descoberto por Marilena no segundo ano de graduação, graças ao professor Lívio Teixeira que a soube "conduzir como que pela mão" através de uma Ética que lhe parecia "impenetrável" 10 (generosidade por que a ex-aluna sempre demonstrou enorme gratidão), além de proporcionar a fascinante e indelével experiência de, ao cabo de uma aula sobre a quinta parte do livro, vislumbrar aquilo mesmo que procurava e lhe motivara inclusive a carreira filosófica, isto é, uma liberdade desintrincada dos dilemas cristáos em que se criara e que a atormentavam; em suas palavras, "o problema de uma culpa originária, de uma culpa maior do que ser culpado disto ou daquilo e o problema de como era possível que um Deus justo e misericordioso me tivesse criado para deixar que eu pecasse para depois me punir"

9 Cf. Chaui, I98I, p. 200: "uma filosofia, como toda experiência de pensamento, nasce no fluxo e refluxo da história pessoal e social, na tentativa para alcançar a inteligibilidade dessas experiências, e portanto, não é um resultado, uma coisa ou fato, mas começo e recomeço, um instrumento de trabalho."

Para as circunstâncias do trabalho de Marilena, além do já citado, nos apoiaremos nas seguintes entrevistas: Chaui, I982, 2000, 2014. Duas observaçóes: I) no caso particular da entrevista de 2000, ao lado da versáo editada e publicada, utilizamos também a versáo original, bem mais extensa; ao remetermos a ela, em vez do número de página daremos a indicação "inédito" e cuidaremos de oferecer o trecho em questão; 2) não vamos nos preocupar em especificar, a cada passo, a fonte da informaçáo; para os casos de divergências entre os relatos (em número pequeno mas considerável), adotamos o ponto de vista que nos pareceu mais razoável a partir do cotejo dos documentos.

10 "Quando comecei a estudar Espinosa, fiquei quase paralisada, pois não conseguia entender uma única palavra. Era impenetrável.” (Chaui, 200I, p. I406) 
(Id., 2000, p. 303). Nada mal para uma graduação. Fato, porém, é que esse lampejo pouco decorre da compreensão do próprio texto espinosano. Ou seja, caso se queira supor que "nascia ali a Marilena espinosana" (De Paula, 20I7, p. I62), mister é reconhecer na sequência que a filiação indicada pelo adjetivo só ganha sentido razoável se entendida como efeito do fascínio de uma revelação de si no espelho de outrem, pois que não fora ainda sobrepujado "um problema muito sério", inevitável de ser encarado por quem excogita uma tese sobre o espinosismo: "não consigo ler Espinosa" ${ }^{11}$ E tendo isso em mente é que vem à tona uma dúvida. Na concorrência pela dedicação da novíssima doutoranda, ao lado do filósofo holandês, estava um outro "clássico" de peso, o autor da Fenomenologia do espírito, cuja leitura no mestrado, conta ainda Marilena, produziu-lhe efeito de total incompreensão similar àquele da Ética e lhe interessara mormente pelo tratamento da "consciência infeliz". Nessas circunstâncias, por que um clássico em vez do outro?

Percebi, então, que era sempre a mesma questão, que iria ler Hegel pelos mesmos motivos que desejava ler Espinosa e voltei a Espinosa. Porque achei (não sei hoje se diria o mesmo), mas achei que Espinosa, de alguma maneira, apontava uma relação entre o finito e o infinito e a liberdade sem passar pelo grilhão de culpa [...] foi o cristianismo de Hegel que me afastou dele, porque nós éramos "iguais". (Chaui, I982, p. I8)

Vale observar que essa concorrência montada na cabeça da jovem doutoranda, um dos mais célebres dérbis da filosofia contemporânea e à época atiçado pelos althusserianos, desponta aqui e ali discretamente no mestrado, graças ao arsenal merleau-pontyano da crítica ao humanismo que Marilena reconstitui tomando por mote a derradeira anotaçáo d'O visivel e o invisivel, ${ }^{12}$ arquitetura nascida de uma providencial, e quiçá sintomática (o segredo espinosano em ação?), desobediência ao plano inicialmente traçado com o orientador a partir dos interesses da estudante (a relação entre filosofia e marxismo) e que a leva a desbravar inéditas searas. ${ }^{13}$

${ }^{11}$ Chaui, 200o, inédito: à saída da mencionada aula sobre a Ética $V$, o professor “me perguntou: 'Então, a Sra. acha que encontrou a resposta para as suas perguntas?' Ao que respondi: 'Acho que encontrei, mas tenho um problema muito sério: não consigo ler Espinosa'. E até lhe disse que a minha dissertaçáo estaria baseada nas aulas e nos comentadores, e não nos livros de Espinosa. O Prof. Lívio me disse então: 'Tenha calma! Um dia a Sra. conseguirá entendê-lo!'.”

${ }^{12}$ Cf. Merleau-Ponty, 2006, p. 328, apud Chaui, I967, p. I-2: "Meu Plano: I o visível; II a natureza; III o logos. Deve ser apresentado sem nenhum compromisso com o humanismo, nem com o naturalismo, nem, enfim, com a teologia. Trata-se precisamente de mostrar que a filosofia náo pode mais ser pensada segundo essa estratificação: Deus, Homem, Criaturas, — que era a estratificação de Espinosa.”

${ }^{13}$ Chaui, 200o, p. 304: "Bento Prado, meu orientador, me propôs o tema (a crítica do humanismo) e um roteiro de trabalho que começava em Sens et Non sens e iria terminar n'As aventuras da dialética. No entanto, em vez de começar por Sens et Non sens, comecei esse itinerário pel'O visível e o invisível, me detive na primeira [sic; na verdade é a última] nota de trabalho das Notas colocadas no fim do livro, e acabei mudando meu percurso, concentrando-me nas questóes de fenomenologia e ontologia e As aventuras da dialética sequer entraram na 
A quem lê a dissertação de 1967 salpicando-a com aquela pitada de anacronismo que já admitimos, não parecerá absurda a armação. Embora na referida nota o plano de Merleau-Ponty seja negativamente esboçado a partir da distância que ele pretende tomar com relação à "estratificaçáo de Espinosa", fato é que esse fundo negativo não perde seu caráter justamente de fundo, e portanto, como estaria cansada de saber uma leitora dos gestaltistas, condição para a percepção da figura visada. O que Merleau-Ponty pretende rechaçar emoldurando lado a lado vertentes filosóficas tão díspares (humanismo, teologia, naturalismo), explica-nos Marilena, é um "pressuposto comum" a todas, qual seja, a pretensão de estipular "uma origem absoluta de todos os seres e de toda verdade a partir de uma raiz única”, de modo que Deus, Homem, Natureza tornam-se termos "homônimos e substituíveis".

Da teologia ao humanismo, deste ao naturalismo não há modificação essencial na investigação filosófica. Em todas essas posturas a filosofia aceita as facilidades de uma só entrada. Cada um desses termos, face de um anseio comum, é tomado como princípio explicativo absoluto e que poderia ser substituído, em sua função, por outro. (Id., 1967, p. 2)

Perguntar-se-á com pleno direito: mas não será o espinosismo da radical unicidade da substância a filosofia que mais perfeitamente realiza esse mau pressuposto da única entrada? Como de praxe, tudo depende da forma como se entende o Deus espinosano, especialmente o tópico crucial das relaçóes entre a substância e os modos, o todo e as partes, ou ainda (saudando o Heidegger bastante presente na dissertação) o ser e os entes - e os passos da mestranda sugerem que ela em definitivo não interpretava de maneira simplória a nota d'O visivel e o invisivel. É assim que, no combate ao "monstro hegeliano" que todos os indivíduos submete a um destino único que lhes rouba as almas e as singularidades, ${ }^{14}$ ela convoca em aliado o autor da Ética: "enquanto para Espinosa o modo é uma parte integrante mas separável do Todo e que pode ser compreendida por sua oposição com as demais partes, em Hegel os seres individuais perdem toda sua positividade para serem envolvidos pela atividade do espírito" (Ibid., p. I7). O alcance dessa correção espinosanamente operada de uma má concepção das relações entre partes e todo assoma-se no desenrolar do trabalho, mesmo quando o filósofo holandês já não é nomeado. A recusa do

\footnotetext{
dissertação. Se o trajeto inicialmente planejado era resultado da minha formação na graduação, ainda que ajustado pelo Bento, as leituras novas que tive de fazer - A fenomenologia da percepção, A estrutura do comportamento - acabaram levando-me à crítica merleau-pontyana das filosofias da reflexão e da representação, do empirismo e do objetivismo cientificista, e determinaram minha relaçáo com a filosofia daí em diante."

${ }^{14}$ A fórmula "monstro hegeliano" é invocada por Chaui (1967, p. I40) e devidamente remetida (p. XIV, nota 74) à crítica merleau-pontyana, em "A linguagem indireta e as vozes do silêncio", do Museu imaginário de André Malraux. O que vale para a pintura também vale para a ontologia e valerá oportunamente para a história da filosofia.
} 
humanismo, conclui-se, implica a "recusa da metafísica ocidental que abandonando o ser ocupou-se dos entes e colocou no lugar do ser um ente - o homem", e por isso a nova filosofia toma a forma de uma "ontologia", "uma volta ao Ser" (Ibid., p. 267); e embora a coincidência com Heidegger seja nítida, isso não o isenta de reparos de monta, e dele se afasta Merleau-Ponty em dois aspectos fundamentais: primeiro, o ser e os entes não se distinguem; segundo, o ser não é o nada (Ibid., p. 27I); pelo contrário, o ser é multiplicidade. "O que realmente interessa a MerleauPonty é que a multiplicidade não destrói o ser, é sua essência. Para Merleau-Ponty o ser não é o nada porque é multiplicidade. O ser é totalidade.” (Ibid.) Entendamos bem o curioso desse movimento. O cumprimento do programa mais ou menos heideggeriano sugerido na última nota d'O visivel e o invisivel faz Merleau-Ponty ir se afastando de Heidegger conforme a exigência de uma nova ontologia se imponha (e Marilena insiste sem parar que somente a via ontológica pode dar conta dos problemas da tradição) e o "ser de indivisão" vá ganhando tonalidades espinosanas. "O Ser é a totalidade de que as dimensões são pars totalis" (Ibid., p. 274); desde que rejeitada a distinção dualista entre o visível e o invisível, a extensão e o pensamento, o ilusório e o real, o falso e o verdadeiro (cf. Ibid., p. 290), Merleau-Ponty precisa reconceber essas categorias, se as quiser comunicáveis e reversíveis, como "dimensôes igualmente essenciais do Ser" (Ibid., p. 289). ${ }^{15}$

Fechado esse longo parêntesis, voltemos ao momento de eleição de um tema de doutorado. Marilena deixa para trás a contemporaneidade fenomenológica para dedicar-se a um clássico; preterindo Hegel abraça o Espinosa "secretamente" visado desde a graduação; as escolhas porém não tomam a forma do incisivo aut-aut: o espinosismo toma a dianteira, mas a bem dizer a temática não trai as origens e, na esteira de seu interesse por Hegel e Merleau-Ponty, ela planeja uma tese de doutorado decidida às questóes do negativo e da contingência, ou melhor, à crítica e recusa espinosana dessas noçóes. ${ }^{16}$ Em outubro de 1967, já como professora do Departamento de Filosofia da USP, finalmente desembarca em Clermont-Ferrand com o objetivo de estudar sob a orientação de Victor Goldschmidt.

\footnotetext{
${ }^{15}$ Como não ouvir ecos espinosanos nessa maneira de ler Merleau-Ponty? Veja-se, por exemplo, Chaui, I977, II, p. 206: Espinosa busca "uma articulação interna entre os modos (infinitos e finitos) capaz de mantê-los como diferentes, mas sem que a diferença implique em que sejam parcelas do real, pois são suas modulaçōes”. Por outro lado, invertendo a questáo, como nấo discernir ecos merleau-pontyanos nos trabalhos que Marilena dedicará a Espinosa? Ela mesma o explica: "Merleau-Ponty marcou-me para sempre e reconheço que minha interpretação de Espinosa năo teria sido possível sem a perspectiva merleau-pontyana" (Id., 2000, p. 320).

16 "A minha ideia era estudar a ausência do negativo na filosofia de Espinosa porque eu estava influenciada pela interpretação de Hegel feita por Gérard Lebrun, meu professor na graduação e que dera nosso primeiro curso de pós-graduação com uma exposição da negaçáo da negação em Hegel, usando o exemplo de Espinosa como o contraponto perfeito da posição hegeliana. E estava também muito interessada, graças a Merleau-Ponty, na
} 
Quando mostrei a Goldschmidt meu projeto, porém, ele ficou um tanto horrorizado, dizendo-me que aquilo era inviável, pois eu estaria tentando procurar em Espinosa algo que não há, estaria tentando colocar para Espinosa questôes que ele exclui de princípio. E eu lhe respondi que queria justamente entender por que ele as exclui. Queria entender o que leva Espinosa a recusar a negaçáo e a contingência, quais os fundamentos dessa recusa. Evidentemente, Goldschmidt, enquanto um historiador da filosofia que trabalhava com a noçáo de responsabilidade filosófica, ou seja, de não ir além daquilo que o filósofo disse explicitamente, escreveu e assinou, náo gostou da minha teimosia. Ele disse que me deixaria continuar, mas que eu não chegaria a lugar nenhum. Eu fiz então uma análise do primeiro capítulo da primeira parte dos Pensamentos metafisicos, e lhe mostrei. Dias depois, me disse que havia gostado muito, e reconheceu que, se me deixasse prosseguir na minha teimosia, talvez aparecesse algum resultado interessante. (Id., 2000, p. 305)

A estação francesa é prodigiosa. Além do previsível deslumbramento com as bibliotecas e o contato com o meio espinosano local, a doutoranda frequenta cursos de Deleuze e Foucault, acompanha os primeiros momentos da mitológica Universidade de Vincennes (assiste inclusive à aula inaugural proferida por Herbert Marcuse em outubro de 68); ${ }^{17}$ frequenta círculos trotskistas, lê Lênin, Trotsky e Mao, descobre os frankfurtianos; trava conhecimento com o filósofo Claude Lefort, discípulo de Merleau-Ponty e que se tornará um grande amigo; em tremendo golpe da melhor sorte, acompanha ao vivo o maio de 68 parisiense, que lhe marcará, em suas palavras, como a efetiva "experiência da possibilidade revolucionária". ${ }^{18} \mathrm{~A}$ aventura políticointelectual, todavia, encontra abrupto e prematuro termo quando ela decide abreviar a bolsa e retornar ao Brasil.

\footnotetext{
questáo da indeterminação e da contingência, que também tinha como contraponto a necessidade absoluta espinosana." (Chaui, 2000, p. 304-305)

${ }^{17}$ Palavra a Chaui (20I7c): Vincennes foi "a primeira e grande universidade crítica, a universidade de esquerda, do mundo"; cheguei "no primeiro dia de aula e haviam improvisado um barzinho, um café, e estava ali Foucault, Deleuze, Derrida, Michel Serres, Louis Althusser, Jacques Rancière [...] uma coisa absolutamente extraordinária, a gente tinha ao vivo e em cores o pensamento francês, não a filosofia francesa, o pensamento francês".

18 “Não dá para descrever, é uma experiência indescritível. Nas ruas, cartazes diziam 'Não há o impossível', 'É proibido proibir'. [...] Vocês não imaginam o que é passar pela experiência da possibilidade revolucionária. É uma coisa, é uma coisa..." (Chaui, 20I4, p. 27-28).
} 
"Trasímaco também intercepta, interrompe, corta; sua intervenção é um curtocircuito na amena indagação de Sócrates." ${ }^{19}$ A tocante imagem de Luiz Salinas exprime à perfeição o modo como às vezes um intelectual é forçado a encarar os acometimentos bastante reais e enfaticamente violentos de uma ditadura e tentar deles desembrulhar-se; por isso mesmo serve-nos a imaginar, quanto a um intérprete é lícito, o impacto da realidade sobre os destinos da pesquisa que estava em pleno desenvolvimento. Não que Marilena fosse uma socrática em gestação nem que seu trabalho de pesquisa implicasse absoluto isolamento com relação aos eventos do tempo (basta o entusiasmo com o maio francês para decretar o contrário), mas é que ela com carinho, emoção e profundidade meditará no futuro sobre a figura do interlocutor de Sócrates tal como pintada e conceituada no livro do colega e amigo. A dor do pensamento violentado, a coragem do recomeço e o esforço de opor aos "herdeiros de Trasímaco", em vez da revolta e da resignação, o trabalho livremente aguerrido do mesmo pensamento. ${ }^{20}$

"Eu achei que tinha obrigação de voltar!" (Id., 2007, p. 57). Marilena retorna efetivamente ao Brasil em dezembro de 1969; a calamitosa situação política do país explica o imperativo. Náo obstante certa ingenuidade com relação ao que de fato acontecia, de resto compreensível da parte de alguém cuja fonte principal de informaçôes era a comunidade de exilados brasileiros e que desembarca no país convencida de que estava em curso um "processo revolucionário", ${ }^{21}$ ela sabia bem que a

${ }^{19}$ A passagem completa: "Como se, de repente, a própria realidade, pegando-me pela palavra, se pusesse a ilustrar e comentar as peripécias abstratas do discurso filosófico, corporificando as teses de Trasímaco, convertendo-as em gestos, transformando-as em manipulação concreta do desavisado pesquisador, até entâo serenamente empoleirado no conforto das especulaçóes pedagógicas. Trasímaco também intercepta, interrompe, corta; sua intervenção é um curto-circuito na amena indagação de Sócrates." (Salinas Fortes, 20I2, p. 27)

20 "O mundo da ditadura não foi um mundo desnaturado, irracional, obra perversa de um Gênio Maligno ou de uma razáo astuta e mesquinha, de forças abstratas e, sim, aquilo que, naquele tempo, Salinas, lendo com seus estudantes $A$ república, de Platão, procurava com seus alunos: o sentido da figura de Trasímaco. Mas para depois, estupefato, descobrir que a filosofia de que dispúnhamos náo podia dar conta das engrenagens do poder e que nem mesmo Maquiavel poderia imaginar-se em tal caricatura de $O$ príncipe. [...] Meditaçáo sobre o destino, o acaso, a adversidade, a razáo e os afetos, despida de heroísmo porque tecida na serenidade dos perplexos, este livro de Salinas é obra do autor em busca de si mesmo. Trabalho do pensamento e obra de liberdade, que por isso mesmo náo cai na armadilha da revolta, essa triste simbiose entre filosofia e política, pois, como escreveu alguém, todo mundo gosta que o filósofo seja um revoltado porque sua revolta apazigua a má consciência e todos podem regressar satisfeitos aos seus costumeiros afazeres. Este livro, erguendo-se contra 'os herdeiros de Trasímaco', diz não à revolta e à resignação." (Chaui, 20I7a, p. I39, I42.)

${ }^{21}$ Cf. Chaui, 20I4, p. 28-29 (ali onde também aparece a expressão "processo revolucionário"): "Vim sem a menor ideia, porque imaginava que o refluxo aqui era como o da França. [...] Sem AI-5, sem censura, sem tortura. Só para [...] terem ideia de como eu estava por fora, me deram material para entregar a determinadas pessoas e nấo tive dúvida, pus dentro de uma Marie Claire e vim. Desci no aeroporto, passei pela alfândega, com tudo debaixo do braço, dentro de uma Marie Claire! [...] Bom, aí cheguei e caí na real. Foi um susto." Num seminário sobre a "ideia de revolução no Brasil", em 25 de junho de 20I9, no Grupo de Estudos Espinosanos do Departamento de Filosofia da USP, Marilena voltou a relatar essa sensaçáo: para muitos no Brasil, 
Faculdade de Filosofia, Ciências e Letras da Universidade de Sáo Paulo que integrava na condição de docente e doutoranda, "um lugar chamado Maria Antonia", como consagrará num de seus mais belos textos, viera abaixo. A altivez aquiliana do ateneu paulistano (que nada ficava devendo a Vincennes, diga-se de passagem) fora escorraçada ao holocausto numa "luta final" que esteve longe de configurar "aquela que libertaria os filhos da terra" (Id., 20I7b), como sonhavam tantos de seus membros. Pelo contrário, fisicamente destruída pelo CCC (Comando de Caça aos Comunistas) com a colaboração da polícia e do exército, fortemente atingida pela prisão, cassação, exílio de professores e estudantes, numa intervenção imediata e truculenta digna de Trasímaco, deu-se a transferência da Faculdade de Filosofia da USP, da central rua Maria Antônia, que nos anos 60 ainda era atravessada por uma linha de bonde - o "da filosofia", talvez, o "da história nacional" segundo uns mais afoitos - para a então periférica cidade universitária situada no bairro do Butantã, onde ainda jaz.

A Faculdade que encontrei quando cheguei em 1969 era outra, era um conjunto de professores e de estudantes dispersos em barracos no campus da Cidade Universitária, completamente desarvorados, com a sensação de que era preciso resistir, mas não se sabia muito bem como resistir, nem contra $o$ que resistir. O que encontrei foi uma escola inteiramente nova, inesperada, que não tinha nada mais, absolutamente nada mais a ver com aquela que eu tinha conhecido nos anos 6o. Talvez, se eu tivesse vivido o desenrolar dos acontecimentos em 67,68 , e no início de 69 , a transformação não fosse sentida por mim de uma maneira táo brutal. Não sei. Mas para quem chegou à Cidade Universitária no ano da graça de 1969 , a sensação era de terra arrasada, de fim de uma época e, naquele momento, a expectativa do nada. $(I d \text {., I982, p. } 9)^{22}$

Não bastassem as dificuldades estruturais generalizadas, o Departamento de Filosofia, em particular, via-se sob o risco de intervenção por parte da reitoria uspiana (entáo ocupada pelo outrora integralista Miguel Reale) devido ao não cumprimento dos requisitos regimentais de titulados em seu quadro docente. Marilena retorna então para integrar-se ao esforço de resistência. "Bento e Giannotti haviam sido cassados; Ruy Fausto se exilara; Osvaldo Porchat estava nos Estados Unidos; os professores franceses retornaram à França. Éramos uns seis”. (Id., 20I4, p. I9I) Contra a ameaça mais imediata, o expediente adotado pelos remanescentes é o apressamento das

\footnotetext{
em verdade sobretudo os universitários, e para a quase totalidade dos que estavam fora, a revolução estava em curso desde meados da década de 60.

22 Para dimensionar com justeza o assunto, é fundamental ainda ler o tocante relato contido em Chaui, $2017 \mathrm{~b}$.
} 
teses e portanto das titulações regimentalmente necessárias. ${ }^{23}$ No caso de Marilena, toma ela o conjunto de notas de trabalho de que dispunha (em especial aquelas sobre o Tratado teológico-político) e compóe, em curtíssimo espaço de tempo, um texto que deposita para a defesa; "por isso se chama Introdução à leitura de Espinosa e foi feito por razóes eminentemente políticas, para assegurar a existência do Departamento de Filosofia da USP" (Id., 2007, p. 57). O ambiente, não só da universidade como do país, necessariamente refletem-se no trabalho, engendrado na tenebrosa noite ditatorial, tanto a "caçada" aos adversários levada a cabo no imediato pós-AI-5, sobretudo por meio dos desaparecimentos, ${ }^{24}$ quanto aquilo que Marilena definirá numa fórmula incisiva, em vista dos anos imediatamente seguintes, como "a experiência do mundo vigiado".

Uma vez aqui, nas circunstâncias terríveis em que a esquerda se encontrava, achei que eu tinha a obrigaçáo política e moral de fazer um trabalho que tivesse algum sentido para quem vive no Brasil. Continuei a preparar o doutorado, mas abandonei o tema da negaçáo e da contingência (ou melhor, da afirmaçáo da causa de si e da necessidade absoluta) e passei a estudar os textos políticos de Espinosa e, neles, a superstiçáo e a violência, trabalhando uma obra de Espinosa que, na época, ninguém trabalhava - o Tratado teológico-político. [...] No início dos anos 70, nós tínhamos não apenas que garantir a existência do Departamento, como ainda viver sob o terror de Estado e a esperança reduzida de que os grupos revolucionários clandestinos pudessem, pelo menos, sobreviver fisicamente, uma vez que sua sobrevida política tinha os dias contados. Saíamos de casa, em direção à universidade, sem a mínima certeza de que voltaríamos à noite. Náo sabíamos se no dia seguinte os alunos estariam lá, se os colegas estariam lá. Havia o DOPS dentro das salas de aula, aparelhos de escuta na sala dos professores. De vez em quando, desaparecia um colega, e ninguém sabia se ele tinha se exilado, se estava preso sendo torturado ou se tinha sido morto. Foi a época do medo em estado puro. (Id., 2000, inédito)

Para lá do objetivo imediato que se insere no esforço departamental, cabe-nos salientar essa reorientação temática, se queremos desvelar a motivação mais íntima do trabalho naquele momento, isto é, compreender esse declarado imperativo de produzir coisa que fizesse sentido para quem vivia sob a ditadura. Os temas iniciais da negatividade e da contingência deixam o primeiro plano e, embora presentes em

\footnotetext{
${ }^{23}$ Algo que já fora tentado, aliás, ao início da ditadura, conforme nos narra Bento Prado Jr. (1989, p. 9) ao apresentar a tardia publicaçáo de sua tese de livre-docência entáo defendida apressadamente: "Depois do golpe de $\mathrm{I}^{\circ}$ de Abril de 1964, o Departamento de Filosofia, que já existia entáo informalmente, decidiu apressar a titulaçáo de seus membros, numa medida defensiva que logo se revelaria vã."

24 "[Caçada] que é feita no silêncio, com a desaparição. Logo que eu cheguei, Heleni Guariba e Emir Sader, cada um em dias diferentes, foram à minha casa, conversamos longamente sobre as açóes revolucionárias previstas. Mas, alguns dias depois, Heleni desapareceu. E Emir foi pro Chile. Era assim.” (Chaui, 20I4, p. 30) A expressão "experiência do mundo vigiado" é utilizada em $i d ., 2017$ b, p. I59.
} 
vários pontos, assim como Merleau-Ponty e Hegel, sobretudo nas abundantes notas complementares alocadas nas $5 \mathrm{I}$ páginas de apêndice, são ressignificados por uma nova configuraçáo de sentido trazida pela alçada à tona dos tratados Teológico-politico e Politico. É verdade que a inflexão política, embora nova em cotejo com o projetado, não o era absolutamente no percurso de Marilena, pois ressoava o plano original do mestrado, que como vimos era um estudo sobre revolução e marxismo na esteira das Aventuras da dialética, além do que a experiência do 68 parisiense já lhe inspirara a guinada à leitura das obras políticas de Espinosa. ${ }^{25} \mathrm{~A}$ efetiva novidade, pois, reside no concerto dessas questôes todas a uma intenção política e polêmica que responde imediatamente às pressóes do tempo, experiências dolorosas e interrogaçôes urgentes, produzindo um exemplo notável de exercício de história da filosofia orientado pelo presente e que porta em si o germe da obra futura. Com efeito, é ali que a autora consuma, não obstante a brevidade da redação, pela primeira vez e sob o prisma espinosano, o tratamento teórico do tema do autoritarismo que empenhará a sua geração da Faculdade de Filosofia da $\mathrm{USP}^{26}$ e a partir de então marcará todo o seu trabalho, na pesquisa e na docência filosóficas, claro, mas igualmente nas investigaçóes sobre o Brasil que ela realizará principalmente nos anos 70 e 80. Uma vez que o foco do trabalho recai sobre o tema da superstiçáo, estrategicamente compreendido como trama conceitual do espinosismo, Marilena consegue enfronhar-se diretamente nos temas que lhe interessam aprofundar em vista de sua experiência: a violência, o autoritarismo, a história, a resistência, a transformação política. Ou seja, em conformidade com o relato aduzido acima, o trabalho se debruça sobre o espinosismo animado pelo intento de promover a crítica do instituído, e é nessa medida que podemos falar, de maneira rigorosa, de um Espinosa em luta com a ditadura brasileira. Combate cauteloso porém decidido, cuja condição de possibilidade é nada menos nada mais que uma engenhosa operação historiográfica. Convém esclarecer. Não queremos dar a entender que o doutorado de Marilena torne-se o suporte de um discurso críptico que, nascido da ânsia de tratar do presente e da simultânea consciência dos riscos embutidos no ato, lançasse máo do artifício alegórico de falar de uma coisa pretendendo significar outra; ou então, que entregasse ao leitor um enigma a ser decifrado pelo suprimento da distância entre o espírito e a letra, a intenção camuflada nas entrelinhas e o texto, ou pretexto, explícito - uma obra

\footnotetext{
25 "Em fevereiro de 1968, meus estudos iniciaram pelos Pensamentos Metafísico, devendo seguir para o Tratado da Emenda e depois para a Ética. Logo fui para Paris, peguei o maio de 68, e evidentemente, pulei essas obras e fui direto ler o Tratado Político e o Tratado Teológico-Politico!" (Chaui, 2007 p. 56)

26 "O que se criou foi um clima de solidariedade e com um fenômeno muito interessante, não sei se aconteceu nos outros lugares da universidade, mas na filosofia, ciências e letras aconteceu. Era o seguinte: tínhamos um inimigo claro, que evidentemente era a ditadura, mas através da ditadura se constituiu para nós a figura do inimigo político para sempre, que era o autoritarismo." (Chaui, 20I4, p. 3I-32)
} 
portanto cujo estatuto se assemelhasse àquele que Leo Strauss atribuiu ao Tratado teológico-político. ${ }^{27}$ Para dizer de modo simples e direto: o texto de 1970 é uma tese de doutorado sobre Espinosa e corresponde ao que disso se espera, quer dizer, um estudo sobre a filosofia espinosana - como estipula a autora, para o historiador da filosofia, "a imanência da pesquisa ao seu objeto" é a "sua carga" (Id., I97Ia, p. 26). A chave da conciliação entre o gênero tese (estritamente respeitado apesar da pressa) e o uso do espinosismo reside na motivação do trabalho, que no final das contas explica por que ler Espinosa e sobre ele escrever naquele momento, naquele hoje. Para invocar uma fórmula merleau-pontyana muito cara a Marilena, a chave se esconde em seu motivo central: configuração de sentido, "é o que vai surgir e, ao mesmo tempo, o que guia o surgimento"; origem, "não como uma 'causa' passada, mas como inquietação que motiva a obra sustentando seu fazer-se presente". ${ }^{28}$ Envolto pelo medo avassalador (“em estado puro", “permanente”!) o pensamento inquieta-se e precisa resistir, esforça-se em descobrir um meio de fazê-lo como pensamento: cautelosa diligência em compreender o presente e os seus fundamentos, interrogar o que lhe faz sofrer, de tal forma que possa tanto superar o lamento paralisante, por meio da elaboraçáo da experiência da violência e do horror, quanto escapar à tentação das perigosas alternativas de embate frontal; um movimento que vai até o ponto em que a inquietude possa ganhar expressão conceitual, desencadeando um ato de sentido e revigorando as possibilidades de ação. Mais uma vez, cuidemos de nos explicar bem. Não estamos ventilando que o texto deva ser lido sob o prisma do biografismo ou da conjuntura, formas de determinação opressiva que igualmente perdem o trabalho do pensamento. O próprio doutorado, como veremos, rechaça essa má direção interpretativa, que pouco caso faz daquela distinção que já mencionamos como perene nos trabalhos filosóficos de Marilena: a crucial diferença entre um "contexto" que concebe a história fora do texto e "circunstâncias" que nos despertam para o modo como um autor experimenta e vivencia o

\footnotetext{
${ }^{27}$ Cf. Strauss, 20I5, p. 36: "A perseguição [...] dá origem a uma técnica de escrita peculiar e, com ela, também a um tipo de literatura peculiar, na qual a verdade sobre todas as coisas cruciais é apresentada exclusivamente nas entrelinhas." A posição de Strauss será criticada em Chaui, I977, II, p. 222, 234. Quanto à distinção entre "espírito e letra", além de não caber no quadro teórico de uma intérprete que trabalha com a noção de impensado, segundo Marilena ela é "de origem religiosa, pois foi inaugurada pelos teólogos judaicos e cristáos como cânone para a leitura e intepretação da Bíblia" (Id., 20I8b, p. 555); não por acaso a distinçáo é recusada pelo Espinosa intérprete escriturístico.

${ }^{28}$ Leia-se a inteira passagem, pois a ela retornaremos adiante: "Merleau-Ponty fala em motivo central de uma filosofia, e náo em conceito central. Como numa tapeçaria, numa renda, num quadro ou numa fuga, nos quais o motivo puxa, separa, une, enlaça e cruza fios, traços ou sons, configura um desenho ou tema à cuja volta se distribuem os outros fios, traços ou sons, e orienta o trabalho do artesão e do artista, assim também o motivo central de uma filosofia é constelação de palavras e de ideias, uma configuraçáo de sentido. O motivo é o que vai surgir e, ao mesmo tempo, o que guia esse surgimento. Donde seu segundo sentido: o motivo como origem. Náo como uma 'causa' passada, mas como inquietaçâo que motiva a obra sustentando seu fazer-se no presente." (Chaui, I98I, p. I94-I95)
} 
seu tempo, ou seja, que nos cobram "reencontrar a via percorrida pela reflexão quando a matéria com que trabalha vem marcada pelo solo histórico onde germinou" (Id., I977, I, p. I24). É bem verdade, admita-se, que nem Pascal nem Leibniz tiveram a possibilidade de "pensar uma experiência da política que revela a contrapelo os sustentáculos imaginários da tirania", como o pôde Espinosa graças ao "fato de que as Sete Províncias do Norte tenham tentado uma prática política republicana". Não confundamos, porém, a "oportunidade de pensamento" e a fatalidade de pensar assim e assado. "Se confrontarmos, por exemplo, as posiçóes de Espinosa e de Locke, este último, sido contemporâneo do período cromwelliano e da Revolução Gloriosa, torna-se patente que se o evento político suscita a reflexão, nem por isto o pensador está fadado a compreendê-lo criticamente." (Ibid., I, p. I24-I25) O trânsito entre a experiência e o conceito, e portanto a dissolução da ilusão gêmina de um interior ou de um exterior puros da filosofia, tematizada no mestrado e que constituirá um dos pressupostos do doutorado, ganha formulação madura no procedimento de leitura adotado na tese de livre-docência quando, afirmando que uma grande obra nasce do entrelaçamento dessas dimensóes, justifica-se a relevância da biografia espinosana tomada como "referencial" — jamais causa — "para a leitura da obra", na medida em que nos fornece balizas para contemplarmos "o trabalho da reflexão filosófica, enquanto metamorfose operada sobre a matéria da experiência, conduzindo-a à dimensão do conceito, transfigurando imagens que paralisam o pensamento e a ação em um discurso capaz de pensá-las e de inaugurar uma possibilidade nova de agir" (Ibid., I, p. I25).

Não queremos sugerir outra coisa da tese de doutorado de Marilena. Ela se insere numa situaçáo determinada e propóe um estudo e um uso determinados do espinosismo. As circunstâncias particulares atribuem um sentido particular à discussão historiográfica que ocupa toda a primeira parte do trabalho. Náo é impossível que o material resultasse de um exercício preparatório a ser posto de lado quando da redação final; tampouco o é que a mesma discussão e as mesmas teses viessem a preceder o estudo da recusa espinosana das noçóes de negativo e contingência se o doutorado tivesse sido finalizado conforme o plano inicial. Impossível mesmo é deixar de perceber que as páginas do doutorado dedicadas ao problema da leitura (a operação historiográfica apontada há pouco), no interior do trabalho em que se situam, produzidas nas circunstâncias em que o foram, não se resumem a aflorar algumas questóes corriqueiras na história da filosofia (como escrever sobre um filósofo? como lê-lo? como interpretá-lo? etc.). Pouco importando qual destino num primeiro momento lhes coubesse, elas ganham um alcance completamente novo ao possibilitar o percurso do trabalho e sua particularidade, e desse modo assumem o 
teor inaugural da leitura de Espinosa por Marilena tal como assinalamos. A interrogação "como datar um filósofo?", que intitula a primeira parte da tese, abriga uma série de outras (como o filósofo e o texto se relacionam com a história? o que é interior a uma filosofia? o que lhe é exterior? como se insere uma filosofia no tempo e com ele se relaciona?) que culminam numa reflexão sobre a própria possibilidade da empresa em questão. Adequadamente posto, o problema da dataçáo conduz diretamente ao das relaçóes do filósofo e de sua filosofia com o tempo, em duplo sentido: o seu e o dos outros. Por um lado, como ele se situa em face de seu presente e como se relaciona com o seu passado; por outro, como está situado no presente dos outros, inclusive o nosso, que é o seu futuro. A operação serve a respaldar o uso de Espinosa para compreender e enfrentar a situação brasileira. A via privilegiada para essa fundamentação de um espinosismo, por assim dizer, transdata e a decorrente prática de uma leitura adequada a essa condição, sem nada ceder à ilusão de filosofia perene, é a do aprofundamento, especialmente a partir de Merleau-Ponty, da noçáo de clássico. O clássico, ou melhor, a obra de pensamento entendida como clássica faz explodir a datação rígida em virtude de sua ambiguidade essencial: ela "está e não está datada" (Id., I979, p. III; grifos nossos); exatamente por se agarrar fortemente a seu tempo é que pode falar ao nosso, abrindo o caminho para a investigaçâo e permitindo a aquisição do investigado. "Estão aí os clássicos", explica Merleau-Ponty em palavras célebres, e "nisto os reconhecemos: ninguém os toma ao pé-da-letra e, entretanto, os fatos novos não estão nunca absolutamente fora de sua competência, arrancam deles novos ecos, desvendam neles novos relevos." (Signes apud Id., I971a, p. I04)

É essa operação inaugural que nos introduz ao âmago da leitura de Espinosa por Marilena Chaui: uma vigorosa reflexão sobre a temporalidade especifica dos clássicos que, motivada por um peculiar nexo entre conceito e experiência, permite um rigoroso abrasileiramento do espinosismo por meio da articulação entre "investigação" e "aquisição" que franqueia o uso dessa filosofia como instrumento de resistência ao presente ditatorial e questionamento das possibilidades de transformaçáo desse quadro tenebroso.

\section{Referências bibliográficas}

Chaui, M. (1967). Maurice Merleau-Ponty e a crítica ao humanismo. Dissertação de mestrado. Departamento de Filosofia, FFCL-USP.

Chaui, M. (I97Ia). Introdução à leitura de Espinosa. Tese de doutorado. Departamento de Filosofia, FFLCH-USP.

Chaui, M. (197Ib). "A linguagem na filosofia de Espinosa. À guisa de introdução”, Discurso, São Paulo, n. 2. 
Chaui, M. (I97IC). "Respostas às críticas feitas pelo Dr. Arnold von Bugenhagen à tese de doutoramento Introdução à leitura de Espinosa”. Departamento de Filosofia, FFLCH-USP. Texto Inédito.

Chaui, M. (1977). A nervura do real. Espinosa e a questão da liberdade. Tese de livredocência. Departamento de Filosofia, FFLCH-USP, 2 vol.

Chaui, M. (1979). "Política e profecia”, Discurso, São Paulo, n. Io.

Chaui, M. (198I). "Experiência do pensamento". In: Chaui, M., Da realidade sem mistérios ao mistério do mundo. São Paulo: Brasiliense.

Chaui, M. (1982). "Entrevista", Trans/Form/Ação, Sáo Paulo, n. 5.

Chaui, M. (2000). "Entrevista”. In: Nobre, M.; Rego, J. M. (org.). Conversas com filósofos brasileiros. São Paulo: Ed. 34 .

Chaui, M. (200I). "Mea philosophia”. Entrevista a Bento Prado Jr. In: Nascimento, M. M. do (org.). Jornal de Resenhas. São Paulo: Discurso Editorial, vol. II.

Chaui, M. (2002). “A noção de estrutura em Merleau-Ponty”. In: Chaui, M. Experiência de pensamento: ensaios sobre a obra de Merleau-Ponty. São Paulo: Martins Fontes.

Chaui, M. (2007). "A descoberta de Espinosa no século 20". Entrevista a Éricka Marie Itokazu, Homero Santiago e Marta Vitória Alencar. Discutindo Filosofia, São Paulo, n. 8.

Chaui, M. (20I4). "Entrevista à Caros Amigos". In: Chaui, M., A ideologia da competência. Belo Horizonte: Autêntica; São Paulo: Fundação Perseu Abramo

Chaui, M. (20I6). A nervura do real. Imanência e Liberdade em Espinosa. São Paulo: Companhia das Letras, vol. II.

Chaui, M. (2017a). "Salinas: linguagem e violência". In: Chaui, M., Sobre a violência. Belo Horizonte: Autêntica.

Chaui, M. (20I7b). "Um lugar chamado Maria Antônia”. In: Chaui, M., Sobre a violência. Belo Horizonte: Autêntica.

Chaui, M. (20I7c). Depoimento feito nas "Jornadas Foucault". Departamento de Filosofia, FFLCH-USP, I8 de abril de 20I7; disponível em: https://www.facebook.com/espinosanosusp/videos/I2738444639378II2/?v=I273844639378II2

Chaui, M. (2018a). “A filosofia como vocação para a liberdade”. In: Chaui, M., Em defesa da educação pública, gratuita e democrática. Belo Horizonte: Autêntica.

Chaui, M. (20I8b). "Fazer história da filosofia". In: Chaui, M., Em defesa da educação pública, gratuita e democrática. Belo Horizonte: Autêntica.

Chaui, M. (20I8c). "Saudação ao mestre”. In: Chaui, M., Em defesa da educação pública, gratuita e democrática. Belo Horizonte: Autêntica.

Chaui, M. (2018d). "Sobre o ensino de graduação em filosofia”. In: Chaui, M., Em defesa da educação pública, gratuita e democrática. Belo Horizonte: Autêntica. 
De Paula, M. F. (20I7). "Quando Marilena Chaui encontrou o Deus de Espinosa”, Cadernos espinosanos, São Paulo, n. 36.

Gueroult, M. (1968). Spinoza. Dieu. Paris: Aubier-Montaigne.

Merleau-Ponty, M. (2006). Le visible et l'invisible. Paris: Gallimard.

Oliva, L. C. (2020). "Espinosa na universidade brasileira”. In: Bregantini, D. Marilena Chavi: pensamento, afetos e análise da obra. São Paulo: Editora Cult.

Prado Jr., B. (1989). Presença e campo transcendental. Consciência e negatividade na filosofia de Bergson. São Paulo: Edusp.

Salinas Fortes, L. R. (2012). Retrato calado. São Paulo: Cosac Naify.

Siviero, J. M. (20I7) "As novas aventuras da filosofia - Marilena Chaui lendo Merleau-Ponty", Cadernos espinosanos, n. 36 .

Strauss, L. (2015). Perseguição e a arte de escrever. São Paulo: É realizações. 